https://doi.org/10.28925/1609-8595.2021.3.6

UDC 378.091.59:316.46

\author{
Olena Hulko \\ ORCID iD 0000-0002-7924-4141
}

Teacher of Department of Pedagogy,

Psychology And Professional Methods,

The Hrushevsky Humanitarian Pedagogical College,

1 Hrushevsky Sq., 23000 Bar, Ukraine,

gulkolena@ukr.net

\title{
THE INFLUENCE OF STUDENT GOVERNMENT ON THE DEVELOPMENT OF FUTURE TEACHERS' LEADERSHIP QUALITIES
}

The article theoretically substantiates the influence of participation in student government on the development of leadership qualities of future teachers.

The complex of leadership qualities of a modern teacher, which is formed in higher education students during their studies in the higher education institution (HEI), namely initiative, organization, communication, responsibility, creativity, critical thinking, research qualities, emotional intelligence, social activity, strategic vision, ability to work in a team, social adaptability, ability to lead, tolerance, willingness to come to the rescue, honesty and reliability, has been defined. These qualities will help a future teacher to carry out their own professional activities at a high level; will promote the development of skills to quickly establish contacts; direct class work; find quick and unusual solutions to problems; feel and understand the inner world of others; set short and long life goals and achieve them; work in a team; etc. This indicates that the graduate of the HEI must have a full set of leadership qualities that will contribute to his successful professional activity and will actively influence the development of relevant qualities in his students.

Student government is emphasized as a self-organized activity that develops the leadership qualities of students, skills to work in a team, plan and predict their own team activities, creativity, critical thinking. An example of the implementation of the role-playing game «Day of Student Government», tested by us at Bar Humanitarian and Pedagogical College named after Mykhailo Hrusherskyi, as a component of interactive technology aimed at developing leadership qualities of future teachers in the process of attracting to the activities of student government bodies, is proposed.

Key words: development of leadership qualities; future pedagogue; leadership; leadership qualities; student government; teacher-leader.

Introduction. The global social changes taking place in the Ukrainian society require young people to have qualities that will help them easily adapt to today's fleeting conditions, take responsibility for their own actions, be active, communicative, organized, and thus have highly developed leadership qualities. Therefore, higher education in Ukraine is required to prepare a graduate who is competitive not only in the Ukrainian state, but also competent, able to work and be realized on a global scale.

The Laws of Ukraine «On Education», «On Higher Education», the National Strategy for Education Development of Ukraine for 2011-2021, specify a number of effective mechanisms for developing leadership qualities of future teachers, in particular, through their active involvement in student government.

According to the Concept of the New Ukrainian School, which works on the basis of partnership pedagogy and is focused on the teacher-leader «a leader should come to the children, who can lead, who loves his subject, who teaches it professionally». The requirements outlined in the Concept for the Development of Teacher
Education, the requirements for educational programs for teachers, indicate the need to «instill innovation as a way of thinking and a key tool of leadership in a public partnership, perception of globalization of educational processes and competitiveness as prerequisites for development of systems of pedagogical education» (Concept, 2016).

Analysis of previous research on the problem. Wellknown domestic and foreign educators and psychologists, in particular D. Kreims (2007), S. Kalashnikova (2010), T. Kochubei (2012), O. Romanovskyi (2013) etc. considered the problem of educating leaders, creating conditions for the development of leadership qualities of the individual.

Leadership qualities of higher education students became the subject of dissertation research by $\mathrm{O}$. Koriakina, A. Tiniakova, Yu. Krashchenko, V. Moroz and others. Yu. Krashchenko (2012) substantiated and experimentally tested the effectiveness of the youth project «School of Local and Student government «Leader of the Future» in the development of leadership qualities of future teachers. O. Koryakin's (2015) 
research concerns the pedagogical conditions for the development of constructive leadership of future masters of the humanities in the process of professional training. V. Moroz (2015) focused on the organizational and pedagogical conditions for the formation of leadership qualities of students of higher educational institutions in the process of student government.

The analysis of scientific research revealed that the purposeful development of leadership qualities of students increases their success, increases students 'political popularity in the classroom, makes students more likely to take initiative, and shapes students' beliefs about the determinants of success, affects the development of human capital (Anderson, Fangwen Lu, 2017). Thus, an experimental study by E. Goldman et al. (2021) proved that role plays and action plans helped participants apply and practice leadership skills; self-assessments and feedback from peers and mentors provided specifics for focusing development efforts; and personal growth exercises provided opportunities to reflect and consider fresh perspectives. The conducted analysis of scientific researches showed insufficient attention of scientists to the development of leadership qualities of future teachers. Therefore, we consider it expedient to carry out a theoretical substantiation of the essence of leadership qualities of future teachers and determine the influence of participation in student government on their formation.

The analysis showed that the research relates to certain aspects of the development of leadership qualities of future professionals in various fields. They are aimed at the development of leadership in the process of professional training, the activities of student assets. The authors emphasize the formation of such leadership qualities as leadership skills, communication skills, organizational skills, and the ability to influence followers (Yu. Krashchenko, 2012); activity, initiative, perseverance, independence (V. Moroz, 2015). However, the issues of developing such leadership qualities of higher pedagogical education as responsibility, critical thinking, creativity, emotional intelligence, social activity, strategic vision in the process of student government remain insufficiently researched.

Purpose: based on the results of the analysis of scientific works to theoretically substantiate the set of leadership qualities of teachers, and determine the impact of the game method on the development of leadership qualities of applicants for higher pedagogical education in the process of student government.

Research methods. Theoretical methods of analysis, synthesis, comparison and systematization were used to determine the set of leadership qualities of a teacher and substantiate game method for developing leadership qualities of applicants for higher pedagogical education in the process of student government.

Results of the research. Based on the analysis of interpretations by various sources of the concept of «leadership» as a key definition, we found that in dictionaries it is considered from several points of view: «as part of the socio-psychological mechanism of integration of group activities, through which a person or several people role, direct the activities of the group in both productive and non-productive spheres», as «the influence of authority (formal or informal) of the individual on the behavior of group members or the primary team as a whole» (Sociology: a short encyclopaedic dictionary), as a symbol of power and influence within a social group; that is, to function as a leader means to exercise leadership.

Analysis and comparison of researchers' views on the meaning of the concept of «leadership» (S. Kalashnikova, T. Kochubei, Yu. Krashchenko, Reber, O. Romanovskyi, etc.), allowed us to determine that leadership is a certain type of influence of an authoritative person on a group of people in order to achieve common goals and needs.

The author of numerous books on leadership, D. Kreims (2007) defines leadership qualities as «internal traits or abilities that allow a leader to act effectively, while contributing to the development of the organization» (p. 83). N. Marakhovska (2009) defines the leadership qualities of a teacher as an integrated personal education that contributes to the quality of pedagogical activities, names the following components: motives, knowledge, leadership skills, a stable leadership position. V. Sypchenko (2012) positions leadership qualities as «a kind of socio-psychological qualities of the individual, which reflects a person's attitude to people and society in general, they are manifested in his social behavior and actions» (p. 49). The author is convinced that the formation of leadership qualities should be the core direction of professional training of future teachers.

Leadership qualities of the individual, as well as any other components of the personality structure, must be measured, classified and characterized. The criteria for the development of leadership qualities, described by N. Diatlenko (2014), are the following: the internal readiness of the subject to be a leader, which includes a motivational component (internal readiness to accept the role of leader, desire to perform the functions of a leader, interest in the leader); cognitive component (understanding of the tasks, knowledge of organizational algorithms, knowledge of the rules of effective communication in different situations); practical-effective, which includes the activity component (performance); personal-positional component (perception of the leader by the group, perception of the group by the leader).

As a result of the research, V. Moroz (2015), singled out a list of general leadership qualities of the individual (p. 5):

1) «competence - knowledge of the case in which a person manifests himself as a leader;

2) activity - the ability to act vigorously;

3) initiative - putting forward ideas, suggestions;

4) sociability - openness to others, willingness to communicate;

5) intelligence - the ability to get to the heart of the phenomena, to see their causes and consequences, to determine the main thing;

6) persistence - a manifestation of willpower, perseverance, the ability to bring the case to an end; 
7) self-control - the ability to control their own feelings, their behavior in difficult situations;

8) observation - the ability to see, in passing to note the important;

9) efficiency - endurance, ability to work hard;

10) independence - independence in judgments, the ability to take responsibility;

11) organization - the ability to plan their own activities, to show consistency, concentration».

Having analyzed American scientists researches, O. Ponomarenko (2011) focuses on the results that allowed forming a «portrait of a teacher-leader». It is based on five components, namely personal qualities, abilities, self-knowledge, knowledge of others, character. Personal qualities include energy, camaraderie, and charisma. It is noted that the abilities of a teacher-leader mean his intelligence, experience, mental skills, system worldview, and information culture and so on. The teacher's knowledge of himself presupposes the presence of such a quality as «emotional intelligence, which is characterized by selfdiscipline, the ability to control destructive emotions, flexibility in behavior and self-esteem». The components of «self-knowledge» include psychological health and faith in yourself and your strength.

The author notes that the result of «knowledge of others» is the presence of such qualities in a teacherleader as: empathy and communication skills. The described portrait features of the character of a teacherleader reflect the views on life, the integrity of beliefs and actions (Ponomarenko, 2011).

Analysis and comparison of researchers' views on the essence and components of leadership qualities (D. Kreims, N. Marakhovska, V. Sypchenko, N. Diatlenko, V. Moroz, etc.) allows us to determine that leadership qualities are a set of socio-psychological qualities of an individual enabling him to act effectively and achieve his goal.

O. Nestulia (2018) in the manual «Fundamentals of Leadership» in order to better explain the essence of the leader's personality presents the results of a study by W. Bentis, who proposed to divide leadership qualities into four groups:

1) attention management (the ability to present the goal, future result or direction of activity so that it was attractive to followers and motivated them);

2) goal management (the ability to convey their ideas and visions so that they are clear and carry a deep social and personal meaning, meaning);

3) trust management (the leader's ability to overcome fears, mistrust, communication barriers that prevent his followers from fully trusting him);

4) self-management (the ability to objectively assess their strengths and weaknesses, skillfully compensating for their shortcomings by the strengths of their subordinates).

We fully agree with the proposed distribution of groups of qualities and the leadership qualities of the individual indicated in them, because the essence of modern teacher's activity is the ability to present goals to students and design future results or activities in such a way that motivates students to active learning. The teacher must communicate his ideas and visions at such a level of communication that they are not only understandable to students, but also grow into their personal needs and beliefs, which can be realized in a trusting, partnership relationship between teacher and students. The most important component of the leadership qualities of a teacher-leader is the ability to identify their own strengths and weaknesses, skillfully compensating for their shortcomings with the strengths of their wards, the ability to present their students and class so that students believe in their own strengths and capabilities.

V. Karmanenko (2019) believes that the leadership qualities of students should be attributed to «a variety of socio-psychological qualities of the student's personality, which reveal his attitude to other people and society in general, allow him to effectively influence student group members, and create a positive atmosphere in the team» (p. 53).

From our point of view, M. Vudkok and D. Frensis presented the determinant qualities of leadership quite thoroughly. Researchers include the following qualities:

1. Extraversion (represented by such characteristics as persistence, energy, activity).

2. Neuroticism (represented by such characteristics as emotional stability, confidence, endurance).

3. Consciousness (represented by such characteristics as organization, responsibility, reliability, persistence).

4. Benevolence (represented by such characteristics as willingness to cooperate, altruism, kindness) (Cited by Diatlenko, 2014).

The conducted analysis allowed determining the set of leadership qualities of a modern teacher who will successfully work in a secondary school and implement the Concept of the New Ukrainian School:

1) initiative (internal motivation, desire to produce and implement ideas that will benefit the team);

2) organization (constructive planning and streamlining not only of their activities but also of the team);

3) communicativeness (the presence of stable personality traits that contribute to the successful reception, understanding, assimilation, use and transmission of information);

4) responsibility (awareness of their own actions and their consequences for the team);

5) creativity (production of fundamentally new ideas that will contribute to the rapid and effective solution of team tasks);

6) critical (the property of thinking, which is the ability to reflect and analyze their own and team activities or behavior in order to find the best ways to solve problems);

7) research qualities (manifested in observation, the ability to know and objectively assess pedagogical situations and processes);

8) emotional intelligence (understanding of their emotions and feelings of other people in order to form a positive psychological climate as a guarantee of success of teamwork); 
9) social activity (manifested in the ability of the individual to purposeful interaction with the environment and is based on its needs and interests and manifests itself as a conscious inner readiness to act);

10) strategic vision (perspective view of the development and activities of the team, aimed at a preliminary assessment of the results of work);

11) ability to work in a team (focus on interaction between team members and the ability to distribute responsibilities);

12) social adaptability (adaptation of the individual to the requirements and expectations of the participants of the new or changed group);

13) the ability to lead (the ability to inspire, guide, motivate the team to work);

14) tolerance (ability to show respect for others and acceptance of their differences);

15) willingness to come to the rescue;

16) honesty and reliability.

Leadership qualities of future teachers are being developed in the educational process of higher education institution: during the study of disciplines of professional training, participation in educational activities, practical training, etc. The subject of our study is the development of leadership qualities of future teachers and determine the impact on their formation of activities in student government.

The Law of Ukraine «On Higher Education» (2014) defines the system of student government «as a holistic structural mechanism that allows students through selforganized activities to participate in the management of their staff in cooperation with all governing bodies of higher education, protect their rights and interests, promote harmonious development personality of the future specialist, cultivating leadership qualities, social activity». This requires the development of new approaches to the process of developing leadership qualities in future teachers that meet the requirements and value system of civil society (Article 40).

Manifestations of leadership qualities of future teachers are persistent active, responsible social behavior and actions aimed at organizing and managing relationships in the group to achieve collective goals, solve problems and find optimal solutions. Carrying out active activity in student government bodies at the level of academic group or Student council of an educational institution, a student will develop the above-mentioned qualities. Becoming a member of student government, a young person consciously assumes the role of student leader, who must be endowed with certain personal qualities.

As noted by A. Kurytsia and D. Kurytsia (2014), the process of development of leadership qualities of students should be part of a holistic pedagogical process of free education and be based on special conditions that ensure its effectiveness (p. 356). Scientists have identified the following psychological and pedagogical conditions for the effective development of leadership qualities of students:

- taking into account individual psychological char- acteristics and the development of student leadership motivation;

- development of responsibility (from concrete situational to responsibility as a stable personal property) as a basis of responsible leadership;

- creation of a developmental personality-oriented environment in training and real educational and extracurricular interaction of students, which is marked by relevant characteristics (content of activity, group dynamics, problems, reflection); aimed at developing responsibility as the basis of leadership;

- ensuring the purposeful development of leadership qualities of boys and girls through the organization of student staff, student government and the use of interactive forms of work (trainings, role-playing games) (Kurytsia \& Kurytsia, 2014, p. 356).

Summarizing the approaches of scientists, we note that student government is the center in which the personal qualities of young people are honed. After all, before becoming a leader for the environment, a person must form the appropriate qualities that will help him to take a leadership position. By participating in the activities of the student council, future teachers develop the ability to interact with the environment, work in a team, and communicate. M. C. Veronesi and R. B. Gunderman (2012) argue that the experience of student participation in student organizations meets 6 principles of leadership development: ownership, experience, efficacy, sense of community, service learning, and peer-to-peer mentoring. Hsien-Hsien Lau et al. (2014) investigated the positive correlation of graduate participation in various extra-curricular activities and communication, leadership, creativity and self-promotion skills formed during this activity. Researchers have concluded that such activities help graduates in employment.

The use of game technologies actively influences the development of leadership qualities of student youth, formation of skills to plan and forecast their own team activities, several skills such as teamwork, negotiation, social skills or critical thinking (I. Filibi \& I. Alonso, 2015; B. Howard et al, 2014). Research by L. Gjedde (2013) dedicated to how live action role-game playing can function as an overarching framework for learning may offer fresh insights into game-based learning in terms of multimodality, flexibility in the design of games and the role and interactivity of the learner and teacher. The scientist calls role-playing games a platform for creative and collaborative learning that enhances the learners' motivation and zest for learning while developing 21st century learning skills.

N. Kravets and O. Grechanovska (2017) note that «game technologies are a special teaching method that involves learning material and the content of education, forms the interaction of teacher and student through the game, as well as helps to find and get the desired goal, i.e. to achieve a certain result». Game technologies include the following: exercise games, game discussion, business educational game, role play, etc.

For example, we give the sequence of preparation 
and conduct of the role play «Student government Day», tested by us in Municipal Institution of Higher
Education «Bar Humanitarian Pedagogical College named after Mykhailo Hrushevsky» (Fig. 1).

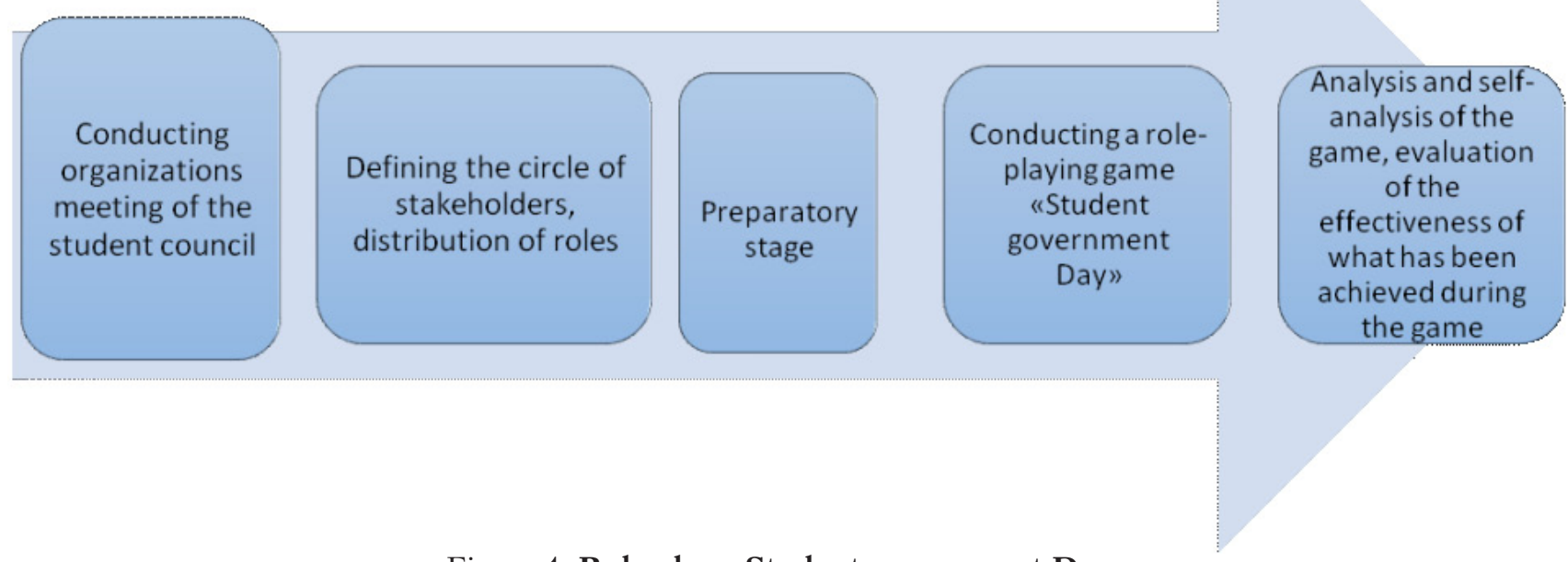

Figure 1. Role play «Student government Day»

Developed by the author

First, there is an organizational meeting, where members of the Student council of higher education institution discuss issues related to the preparation and conduct of the event: division of responsibilities among members of the student council, determination of persons responsible for individual preparatory stages, budgeting members of the college administration among members of the student government. Usually, each member of the student council chooses the role to play during the game. However, among the members of the student council there may be several who want to try themselves in the role of «head of the department» or «dean of the faculty», in this case, we use a draw: the sheet lists the roles that have not yet been selected by the students, and it is suggested that they «blindly» choose their future position.

Traditionally, role-playing takes place on Student's Day, which is celebrated in Ukraine on November 17. On the day of the game, students play the roles of the head of HEI and his deputies, the dean of the faculty, heads of departments, employees of the social and psychological service, etc. Conducting a role play aims to form business, leadership qualities of all its participants and awareness of responsibility for the quality organization of the educational process, as training sessions must take place at the appropriate level. Note that classes with students are also conducted by the students themselves. To do this, a college student who wants to try himself as a teacher of the discipline, receives permission from the teacher and a series of consultations that allow you to conduct interesting, high-quality and productive classes, and most importantly, make sure you have the appropriate pedagogical skills and professional skills. Considering that the college trains specialists not only in the pedagogical profile, students majoring in «Law» and «Journalism» are also very happy to conduct classes in their academic groups and for junior students. In the format of a round table, there is an extended meeting of the leadership of the higher education institution with members of the «student administration»- performers of roles who during the day not only mastered new life and professional experience, but also delegated their powers within their roles. During the meeting, important issues related to the organization of the educational process are discussed for all participants and the results of the role play are summarized.

The role-playing game usually ends with a holiday concert. Joint concert numbers, where the student and teacher show their skills in pairs, show the participants a wonderful concert performance of modern and classical potpourri, the artistry of the actors involved in humorous sketches will not leave anyone in the hall without a cheerful mood. At the celebrations, all attendees receive congratulations from the «young director of the college» (chairman of the student council) and the head of the educational institution, who focus their efforts on creating a favourable psychological climate in the college and its development.

Positive feedback on the Day of Student SelfGovernment in the college from all participants in the educational process, indicate that not only students but also their mentors-teachers, with great pleasure spent the day in informal communication. Quite often, teachers manage to find in students with whom they have worked for more than a year, completely different personal qualities, which contributes to the formation of favourable relationships in the system «teacher-student». At the same time, students have the opportunity to once again «see» their teachers in another role, hear interesting stories about their student years and get through the atmosphere of their student life. For 6 years in a row role-playing has shown that role-playing has 
encouraged students to be more aware and responsible about their responsibilities as members of the student council. During the preparation and conduct of the game, they were proactive, creative, resourceful, demonstrated effective teamwork. The interpersonal relations of the members of the Student council were marked by a change in the forms of interaction; there was an understanding of each other, a desire not to let the team down, a willingness to come to the rescue. The heads of student government, whose council members participated in the role-playing game «Student government Day», noted that their teams have become more organized, responsible, proactive, reliable, tolerant and able to set a goal and achieve it.

Conclusions. The conducted theoretical analysis of scientists' views on the concepts of «leadership» and «leadership qualities» made it possible to determine a set of leadership qualities of a teacher, which includes: activity, initiative, persistence, self-control, observation, independence, organization, communication, responsibility, creativity, critical thinking, emotional intelligence, strategic vision, ability to work in a team, social adaptability and the ability to lead. This set of leadership qualities of a teacher we consider it necessary to divide into components as follows: personal qualities of the teacher, pedagogical abilities and professional qualities.

The influence of student government on the development of leadership qualities of future teachers is determined, which is to involve student youth in organizing and conducting various events: role-playing, trainings, quests, fairs, photo exhibitions, holiday concerts, celebrations, and volunteering. It opens opportunities for each student to try himself not only as a participant in the event, but at different levels of organization and conduct, to take an active part in shaping the educational environment of the educational institution, to feel not only an ordinary student, but a full partner.

Among the various forms of student government, the use of role-playing as a component of interactive technology that can ensure the formation of future teachers the necessary leadership skills for successful professional activity in the modern education system and the New Ukrainian school.

We see prospects for further research in the development of tools for diagnosing the development of leadership qualities of students of higher pedagogical education in the process of student government.

\section{References}

Anderson, M. L., Fangwen Lu (2017). Learning to Manage and Managing to Learn: The Effects of Student Leadership Service. Management Science, 63 (10), 3246-3261. https://doi.org/10.1287/mnsc.2016.2483

Filibi, I., \& Alonso, I. (2015). Ventajas de los juegos cooperativos presenciales en ciencias sociales. Opción, 31 (5), 343-361. https://produccioncientificaluz.org/index.php/opcion/article/view/20657

Gjedde, L. (2013). Role game playing as a platform for creative and collaborative learning. 7th European Conference on Games Based Learning, ECGBL, 1, 190-197.

Goldman, E., Manikoth, N., Fox, K., Jurjus, R. \& Lucas, R. (2021). Faculty leadership development: A case study of a synergistic approach. Medical Teacher, 43 (8), 889-893. https://doi.org/10.1080/0142159X.2021.1931079

Howard, B. B. McClannon, T. W. \& Wallace, P. R. (2014). Collaboration Through Role Play Among Graduate Students in Educational Leadership in Distance Learning. American Journal of Distance Education, 28 (1), 51 61. https://doi.org/10.1080/08923647.2014.868665

Lau, H.-H., Hsu, H.-Y., Acosta, S. \& Hsu, T.-L. (2014). Impact of participation in extra-curricular activities during college on graduate employability: an empirical study of graduates of Taiwanese business schools. Educational Studies, 40 (1), 26-47. https://doi.org/10.1080/03055698.2013.830244

Veronesi, M. C, Gunderman, R. B. (2012). Perspective: the potential of student organizations for developing leadership: one school's experience. Academic medicine, 87 (2), 226-229. 10.1097/ACM.0b013e31823fa47c.

Diatlenko, N. (2014). Liderski yakosti studentiv-psihologiv yak skladova yihnoyi profesijnoyi kompetentnosti [Leadership qualities of students-psychologists as a component of their professional competence]. In Kompetentnisnij pidhid u profesijnij pidgotovci majbutnih psihologiv (pp. 125-133). Vindruk.

Zakon Ukrainy «Pro vyshchu osvitu» [Law of Ukraine On Higher Education] (2014). https://zakon.rada.gov.ua/laws/ show/1556-18

Kalashnikova, S. (2010). Osvitnya paradigma profesionalizaciyi upravlinnya na zasadah liderstva Monografiya [Educational paradigm of professionalization of management on the basis of leadership Monograph]. Boris Grinchenko Kyiv University.

Koncepciya Nova ukrayinska shkola [The concept of the New Ukrainian School] (2016). https://osvita.ua/doc/files/ news/520/52062/new-school.pdf

Kochubei, T., \& Semenov, A. (2012). Suchasni teoriyi liderstva: teoretichnij aspekt [Modern theories of leadership: a theoretical aspect]. Psihologo-pedagogichni problemi silskoyi shkoli, (40), 176-184.

Kravets, N. \& Hrechanovska, O. (2017). Igrovi tehnologiyi navchannya yak odna z innovacijnih form navchalnovihovnogo procesu VNZ [Game learning technologies as one of the innovative forms of educational process of higher education]. Materiali XLVI naukovo-tehnichnoyi konferenciyi pidrozdiliv VNTU. https://conferences.vntu. edu.ua/index.php/all-hum/all-hum-2017/paper/view/2013.

Krashchenko, Yu. (2012). Vihovannya liderskih yakostej majbutnih uchiteliv u sistemi studentskogo samovryaduvannya 
[Education of leadership qualities of future teachers in the system of student government]: Candidate's thesis: 13.00.07. Institut problem vihovannya NAPN Ukrayini.

Krames, J. A. (2007). 4 pravila liderstva Dzheka Uelcha [Jack Welch and the 4 E's of Leadership]. Pokoleniya.

Kurytsia, A., \& Kurytsia, D. (2014). Psihologo-pedagogichni umovi rozvitku liderskih yakostej studentiv [Psychological and pedagogical conditions for the development of leadership qualities of students]. Problemi suchasnoyi psihologiyi, 26, 353-363.

Marakhovska, N. (2009). Pedagogichni umovi formuvannya liderskih yakostej majbutnih uchiteliv u procesi navchannya disciplin gumanitarnogo ciklu [Pedagogical conditions of formation of leadership qualities of future teachers in the process of teaching disciplines of the humanities]: Extended abstract of candidate's thesis: 13.00.04. H. S. Skovoroda Kharkiv National Pedagogical University.

Moroz, V. (2015). Organizacijno-pedagogichni umovi formuvannya liderskih yakostej studentiv vishih navchalnih zakladiv u procesi diyalnosti organiv studentskogo samovryaduvannya [Organizational and pedagogical conditions of formation of leadership qualities of students of higher educational institutions in the process of activity of student government bodies]: Candidate's thesis: 13.00.07. Luhansk Taras Shevchenko National University.

Nestulia, O., \& Nestulia, S. (2016). Osnovi liderstva. Naukovi koncepciyi (vid najdavnishih chasiv do seredini $X X$ st.) [Fundamentals of leadership. Scientific concepts (from ancient times to the middle of the twentieth century)]. PUET.

Nestulia, O., \& Nestulia, S. \& Kononets, N. (2018). Osnovi liderstva [Fundamentals of leadership]. PUET.

Ponomarenko, O. (2011). Problema liderskih yakostej vchitelya $\mathrm{v}$ doslidzhennyah amerikanskih uchenih [The problem of leadership qualities of teachers in the research of American scientists]. Porivnyalno-pedagogichni studiyi, 1 (7), 160-164.

Romanovskyi, O., \& Sereda, N. (2013). Osobistist suchasnogo kerivnika v aspekti teoriyi duhovnogo liderstva [The personality of the modern leader in the aspect of the theory of spiritual leadership]. Teoriya i praktika upravlinnya socialnimi sistemami, (3), 20-27.

Sypchenko, V. (2012). Formuvannya liderskih yakostej u fahovij pidgotovci pedagoga [Formation of leadership qualities in the professional training of teachers]. Pedagogichni nauki, (55), 48-52.

Sociologiya: korotkij enciklopedichnij slovnik [Sociology: a short encyclopedic dictionary] (2020). https://subject.com. ua/sociology/dict/249.html

\section{Список використаної літератури}

1. Anderson M. L., Fangwen Lu Learning to Manage and Managing to Learn: The Effects of Student Leadership Service. Management Science. 2017. № 63 (10). P. 3246-3261. DOI: https://doi.org/10.1287/mnsc.2016.2483

2. Filibi I., \& Alonso I. Ventajas de los juegos cooperativos presenciales en ciencias sociales. Opción. 2015. № 31 (5). P. 343-361. URL: https://produccioncientificaluz.org/index.php/opcion/article/view/20657 (дата звернення 2.09.2021).

3. Gjedde L. Role game playing as a platform for creative and collaborative learning. 7th European Conference on Games Based Learning, ECGBL. 2013. № 1. P. 190-197.

4. Goldman E., Manikoth N., Fox K., Jurjus R. \& Lucas R. Faculty leadership development: A case study of a synergistic approach. Medical Teacher. 2021. № 43 (8). P. 889-893. DOI: https://doi.org/10.1080/014215 9X.2021.1931079

5. Howard B. B., McClannon T. W. \& Wallace P. R. Collaboration Through Role Play Among Graduate Students in Educational Leadership in Distance Learning. American Journal of Distance Education. 2014. № 28 (1). P. 51-61. DOI: https://doi.org/10.1080/08923647.2014.868665

6. Lau H.-H., Hsu H.-Y., Acosta S. \& Hsu T.-L. Impact of participation in extra-curricular activities during college on graduate employability: an empirical study of graduates of Taiwanese business schools. Educational Studies. 2014. № 40 (1). P. 26-47. DOI: https://doi.org/10.1080/03055698.2013.830244

7. Veronesi M. C, Gunderman R. B. Perspective: the potential of student organizations for developing leadership: one school's experience. Academic medicine. 2012. № 87 (2). P. 226-229. DOI: 10.1097/ACM.0b013e31823fa47c

8. Дятленко Н. Лідерські якості студентів-психологів як складова їхньої професійної компетентності. Компетентнісний підхід у професійній підготовщі майбутніх психологів. Вінниця: Віндрук, 2014. С. 125-133.

9. Закон України «Про вищу освіту». URL: https://zakon.rada.gov.ua/laws/show/1556-18/ ed20170928\#n33 (дата звернення: 10.09.2021).

10. Калашнікова С. Освітня парадигма професіоналізації управління на засадах лідерства. Монографія. Київ: Київський університет імені Бориса Грінченка, 2010. 380 с.

11. Концепція Нова українська школа. 27.10.2016. URL: https://osvita.ua/doc/files/news/520/52062/ new-school.pdf (дата звернення 2.09.2021).

12. К Кочубей Т., Семенов А. Сучасні теорії лідерства: теоретичний аспект. Психолого-педагогічні проблеми сільської школи. 2012. № 40. С. 176-184.

13. Кравець Н., Гречановська О. Ігрові технології навчання як одна з інноваційних форм навчально- 
виховного процесу ВНЗ. Матеріали XLVI науково-технічної конферениї̈ підрозділів ВНTУ. 2017. URL: https:// conferences.vntu.edu.ua/index.php/all-hum/all-hum-2017/paper/view/2013 (дата звернення 2.09.2021).

14. Кращенко Ю. Виховання лідерських якостей майбутніх учителів у системі студентського самоврядування: дис... канд. пед. наук: 13.00.07. Київ: Інститут проблем виховання НАПН України, 2012. $200 \mathrm{c}$.

15. Креймс Д. 4 правила лидерства Джека Уэлча. Москва: Поколение, 2007. 336 с.

16. Куриця А., Куриця Д. Психолого-педагогічні умови розвитку лідерських якостей студентів. Проблеми сучасної психологіï. 2014. № 26. С. 353-363.

17. Мараховська Н. Педагогічні умови формування лідерських якостей майбутніх учителів у процесі навчання дисциплін гуманітарного циклу: автореф. дис... канд. пед. наук: спец. 13.00.04. Харків: Харківський національний педагогічний університет імені Г. С. Сковороди, 2009. 22 с.

18. Мороз В. Організаційно-педагогічні умови формування лідерських якостей студентів вищих навчальних закладів у процесі діяльності органів студентського самоврядування: дис... канд. пед. наук: спец. 13.00.07. Старобільськ: Луганський національний університет імені Тараса Шевченка, 2015. 305 с.

19. Нестуля О., Нестуля С. Основи лідерства. Наукові концепції (від найдавніших часів до середини ХХ ст.). Полтава: ПУЕТ, 2016. 277 с.

20. Нестуля О., Нестуля С., \& Кононец Н. Основи лідерства. Полтава: ПУЕТ, 2018. 241 с.

21. Пономаренко О. Проблема лідерських якостей вчителя в дослідженнях американських учених. Порівняльно-педагогічні студіï. 2011. № 1 (7). С. 160-164.

22. Романовський О., Середа Н. Особистість сучасного керівника в аспекті теорії духовного лідерства. Теорія і практика управління соціальними системами. 2013. № 3. С. 20-27.

23. Сипченко В. Формування лідерських якостей у фаховій підготовці педагога. Педагогічні науки. 2012. № 55. C. $48-52$.

24. Соціологія: короткий енциклопедичний словник. 2020. URL: https://subject.com.ua/sociology/dict/ 248.html (дата звернення 2.09.2021).

Стаття надійшла до редакиї 13.09.2021

Прийнято до друку 28.10.2021

\section{ВПЛИВ СТУДЕНТСЬКОГО САМОВРЯДУВАННЯ НА РОЗВИТОК ЛІДЕРСЬКИХ ЯКОСТЕЙ МАЙБУТНІХ ПЕДАГОГІВ}

Гулько Олена, викладач кафедри педагогіки, психології та фахових методик, КЗВО «Барський гуманітарно-педагогічний коледж імені Михайла Грушевського», майдан Грушевського, 1, 23000 Бар, Україна, gulkolena@ukr.net

У статті теоретично обгрунтовано вплив участі в студентському самоврядуванні на розвиток лідерських якостей майбутніх педагогічних працівників. Визначено комплекс лідерських якостей сучасного вчителя, що формується в здобувачів вищої освіти під час навчання у закладі вищої освіти, а саме: ініціативність, організованість, комунікативність, відповідальність, креативність, критичність, дослідницькі якості, емоційний інтелект, соціальна активність, стратегічне бачення, уміння працювати в команді, соціальна адаптивність, здатність вести за собою, толерантність, готовність прийти на допомогу, чесність $i$ надійність. Наведені якості допоможуть майбутньому педагогічному працівникові здійснювати власну професійну діяльність на високому рівні: сприятимуть розвитку вмінь швидко налагоджувати контакти, спрямовувати роботу класу, знаходити швидкі та нестандартні варіанти вирішення проблемних питань, відчувати та розуміти внутрішній світ оточуючих, ставити близькі та далекі життєві цілі й досягати їx, пращювати в команді тощо. Зазначене свідчить, що випускник закладу вищої освіти має володіти повним набором лідерських якостей, які сприятимуть його успішній професійній діяльності та здійснюватимуть активний вплив на розвиток відповідних якостей у його учнів.

Акцентовано студентське самоуправління як самоорганізована діяльність, яка розвиває лідерські якості студентів, навички пращювати у команді та планувати й прогнозувати власну діяльність, креативність, критичне мислення. Запропоновано приклад реалізачії рольової гри «День студентського самоврядування», апробованої нами в Барському гуманітарно-педагогічному коледжі імені Михайла Грушевського, як складової частини інтерактивної технології, спрямованої на розвиток лідерських якостей майбутніх педагогів у процесі залучення до діяльності органів студентського самоврядування.

Ключові слова: вчитель-лідер; лідерство; лідерські якості; майбутній педагогічний працівник; розвиток лідерських якостей; студентське самоврядування. 


\section{ВЛИЯНИЕ СТУДЕНЧЕСКОГО САМОУПРАВЛЕНИЯ НА РАЗВИТИЕ ЛИДЕРСКИХ КАЧЕСТВ БУДУЩИХ ПЕДАГОГОВ}

Гулько Елена, преподаватель кафедры педагогики, психологии и профессиональных методик, Барский гуманитарно-педагогический колледж имени Михаила Грушевского, площадь Грушевского, 1, 23000 Бар, Украина, gulkolena@ukr.net

В статье теоретически обосновано влияние участия в студенческом самоуправлении на развитие лидерских качеств будущих педагогов.

Определен комплекс лидерских качеств современного учителя, который формируется у соискателей высшего образования, а именно: инициативность, организованность, коммуникабельность, ответственность, креативность, критичность, исследовательскиекачества, эмоциональныйинтеллект, социальная активность, стратегическое видение, умение работать в команде, социальная адаптивность, способность вести за собой, толерантность, готовность прийти на помощь, честность и надежность. Приведенные качества помогут будущему педагогическому работнику осуществлять собственную профессиональную деятельность на высоком уровне: способствуют развитию умений быстро налаживать контакты, направлять работу класса, находить быстрые и нестандартные варианты решения проблемных вопросов, чувствовать и понимать внутренний мир окружающих, ставить близкие и дальние жизненные цели и достигать их, работать в команде и т. д. Указанное свидетельствует, ито выпускник высшего учебного заведения должен обладать полным набором лидерских качеств, способствующих его успешной профессиональной деятельности, и осуществлять активное влияние на развитие соответствующих качеств у его учеников.

Акцентировано студенческое самоуправление как самоорганизующаяся деятельность, которая развивает лидерские качества студентов, навыки работы в команде, умение планировать и прогнозировать собственную деятельность, креативность, критическое мышление. Предложен пример реализации ролевой игры «День студенческого самоуправления», апробированной нами в Барскомгуманитарно-педагогическом колледже имени Михаила Грушевского, как составной части интерактивной технологии, направленной на развитие лидерских качеств будущих педагогов в проиессе вовлечения в деятельность органов студенческого самоуправления.

Ключевые слова: будущий педагогический работник; лидерство; лидерские качества; развитие лидерских качеств; студенческое самоуправление; учитель-лидер. 